\title{
ZNF292 Gene
}

National Cancer Institute

\section{Source}

National Cancer Institute. ZNF292 Gene. NCI Thesaurus. Code C142224.

This gene plays a role in growth hormone signaling-dependent regulation of transcription. 